\title{
Diet of the endemic Madeira Laurel Pigeon Columba trocaz in agricultural and forest areas: implications for conservation
}

\author{
PATRICIA MARRERO, PAULO OLIVEIRA and MANUEL NOGALES
}

\section{Summary}

The diet of the endemic Madeira Laurel Pigeon Columba trocaz in agricultural and forest areas of Madeira Island was studied in 1997 by means of microhistological analysis of 157 faecal samples, 94 from two of the main agricultural zones and 63 from a laurel forest. Cabbage was the most important component of the diet in agricultural areas, representing more than $54 \%$ of the optical fields analysed. Samples collected further from the forest contained a higher proportion of cabbage. Native fruits did not figure highly in the samples collected from agricultural areas and crop plants did not appear in the forest samples, suggesting a degree of dietary separation and that some individuals may concentrate on crops. Madeira Laurel Pigeon is normally a highly frugivorous species and fruit availability is relatively high in winter when the birds go to agricultural areas to feed. This suggests that it is not a shortage of natural foods that causes them to leave the forest. The unpopularity of the pigeon as a result of its pest status is the main threat to its existence. More information on the seasonal physiological requirements of Madeira Laurel Pigeon and the pattern of individual use of crops is needed to ensure the future conservation of this species.

\section{Introduction}

Madeira Laurel Pigeon Columba trocaz, endemic to Madeira, is mainly restricted to indigenous laurel forest found on the northern slopes and in a few isolated pockets in the south of the island (Bannerman and Bannerman 1965, Zino and Zino 1986). The laurel forest covers 15,000 ha, about $20 \%$ of the total $737 \mathrm{~km}^{2}$ of the island surface (Costa Neves et al. 1996). In their natural habitat the pigeons, whose population size has been estimated as 8,400 birds (Oliveira et al. 2001), feed on a wide variety of food sources, and more than 33 laurel forest plant species have been recorded in the diet (Oliveira et al. 2002).

Madeira Laurel Pigeon is the major bird pest of the archipelago, visiting agricultural lands close to forest and feeding on a wide variety of crops and fruit trees such as cabbage, peas, beans, watercress, walnut, cherries and peach (Zino and Zino 1986, Oliveira and Jones 1995). Damage caused to agricultural fields, and particularly in cabbage crops, has encouraged the development of illegal methods of control such as hunting and poisoning (Oliveira and Heredia 1996). Under pressure from the agricultural community, in 1985, 1997 and 1998, the Madeira Government set up a contingency plan which involved shooting birds 
both in agricultural fields and in forest (Oliveira and Jones 2001). This measure was taken without any dietary study of the pigeon in agricultural or forest areas being carried out. Although a few other pigeon species have been recorded as damaging cultivated plants (e.g. Neff 1947, Martín et al. 2000), only the effect of Woodpigeon Columba palumbus on crops has been researched in detail (Murton and Jones 1973, Kenward and Sibly 1977, Inglis et al. 1990, Jiménez et al. 1994).

In this work, we studied the diet of Madeira Laurel Pigeon by microhistological analysis of faecal samples. This method is commonly used in research on herbivorous mammals (Martínez 1988, Sherlock and Fairley 1993, Mohammad et al. 1995, Marrero and Martín 2000) but much less frequently on birds (Jordano and Herrera 1981, Rumble and Anderson 1996, Herrera 1998). A recent novel study of the year-round diet of Madeira Laurel Pigeon in its natural habitat has demonstrated that the microhistological technique can provide a very accurate representation of the diet (Oliveira et al. 2002).

There were three aims of the research: (1) to study the dietary composition of the pigeon when feeding in agricultural areas; (2) to confirm the season and situation when crops are attacked; and (3) to study the dietary variation between habitat types (agricultural fields and laurel forest) in order to evaluate possible dietary specialization shown by the individuals that use agricultural areas.

\section{Methods}

\section{Study area}

Madeira Island is located in the eastern Atlantic about $900 \mathrm{~km}$ from Europe and some $630 \mathrm{~km}$ from the African continent $\left(32^{\circ} 38^{\prime} \mathrm{N}, 17^{\circ} 16^{\prime} \mathrm{W}\right)$. The study took place in three localities on the island: Chão da Ribeira (site 1 ), situated at $500 \mathrm{~m}$ a.s.l. in the north-west, consisting of agricultural fields about 50-200 $\mathrm{m}$ from well-preserved laurel forest; Faial (site 2), an agricultural area in the north-east at about $750 \mathrm{~m}$ a.s.l. and more than $300 \mathrm{~m}$ from primary laurel forest; and Ribeira da Janela (site 3), a well-preserved laurel forest area about $2 \mathrm{~km}$ from Chão da Ribeira and $23 \mathrm{~km}$ from Faial. The land in the first two study areas is divided into small terraces where agriculture is a traditional subsistence activity. The fields are intensively cropped, mainly with cabbage Brassica cf. oleracea, potatoes Solanum tuberosum and maize Zea mays. Most of the fields are surrounded by a mix of exotic and indigenous trees.

\section{Sample collection and analyses}

Fieldwork was carried out during 1997 when we visited the agricultural areas during all seasons of that year. However, we only found fresh droppings during the period January-February, just when the pigeons began moving onto cultivated fields. We collected a total of 94 faecal samples from the two agricultural study areas (50 in Chão da Ribeira and 44 in Faial) and 63 faecal samples in Ribeira da Janela during the same winter period. Samples were frozen until they could be analysed by microhistological methods. Plant food items were identified by comparing epidermal tissues with a reference collection. Faecal samples were examined under a microscope, quantifying the presence or absence 
of each plant item within an area observed at $\times 10$ magnification (optical field). We randomly selected 50 optical fields per sample; at the end of the analyses, we had viewed a total of 7,850 optical fields. The potential biases related to the differential digestibility of the food types consumed were evaluated previously by feeding trials with two Madeira Laurel Pigeons in captivity (Oliveira et al. 2002). For more detailed information on methods, see Marrero and Martín (2000) and Oliveira et al. (2002).

\section{Data analysis}

Spearman correlation coefficients were used to relate two dietary variables: total percentage of optical fields containing a food type; and occurrence in the faecal samples. The former was used as the main variable to quantify diet. Likelihood ratio tests were performed to evaluate spatial and habitat differences in the occurrence of a particular plant item. Niche breadth (using percentages of optical fields) was assessed in each study area using the standardized Levins' nichebreadth index $(B)$, where a value close to o indicates dietary specialization and a value close to 1 indicates a broad diet (Krebs 1989). All statistical analyses were performed by using SPSS 10.0 (SPSS 1999).

\section{Results}

\section{Agricultural fields}

Nine plant species belonging to six families were identified in faecal samples (Table 1). Leaves and flowers of cabbage were found in more than $80 \%$ of samples, comprising over $45 \%$ of optical fields. The number of plant species found in samples was similar in the two study areas. Cabbage was the highest food component consumed in both Chão da Ribeira $\left(G_{1}=29.8, P<0.001\right)$ and Faial $\left(G_{1}=867.9, P<0.001\right)$; however, it was relatively more frequent in samples from the latter site $\left(\mathrm{G}_{1}=160.8, P<0.001\right)$. Phyllis nobla and Teline maderensis, typical shrubs from the edges of the laurel forest, were more frequent in Chão da Ribeira $\left(G_{1}=872.6, P<0.001\right.$ and $G_{1}=215.0, P<0.001$, respectively). Ocotea foetens fruits were present only in samples from Faial.

More than $60 \%$ of faecal samples from Faial contained plant remains of only one or two species, while they were more diverse in Chão da Ribeira $\left(G_{1}=35.1\right.$, $P<0.001)$. Furthermore, Levins' niche-breadth index was clearly narrower in Faial $(B=0.07)$ than in Chão da Ribeira $(B=0.24)$. There was a strong correlation between percentages of optical fields and frequency of occurrence in the faecal samples $\left(r_{s}=0.816, P<0.001\right)$, indicating that plant species were not inordinately clumped in particular samples.

\section{Laurel forest}

A clear difference was observed in the pigeon's winter diet between agricultural fields and laurel forest (Figure 1). Whilst leaves of shrub species were predominant in the diet of pigeons from agricultural fields, ripe fruits of tree species constituted the main resource in the laurel forest (Table 1). Phyllis nobla, 


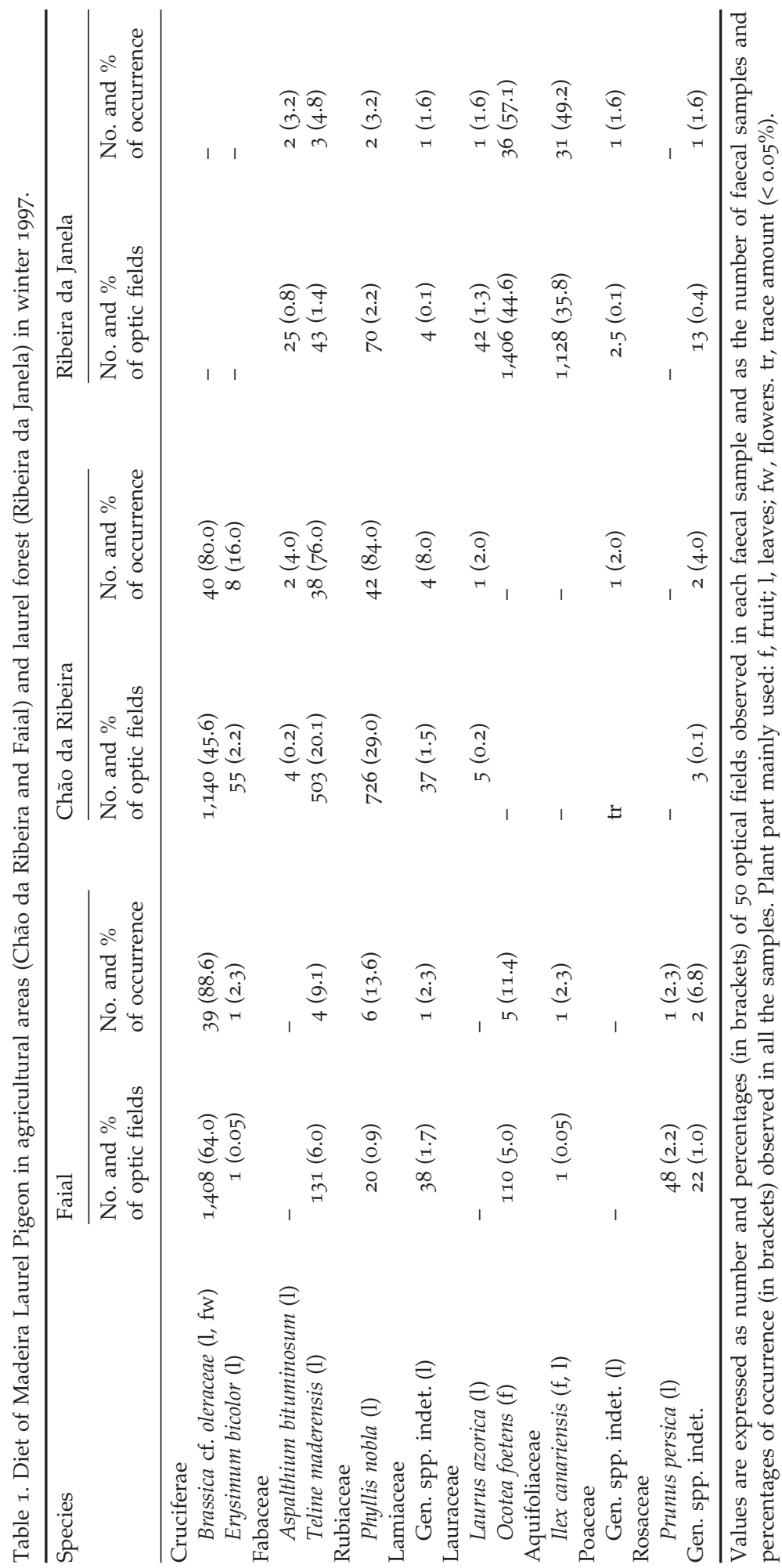




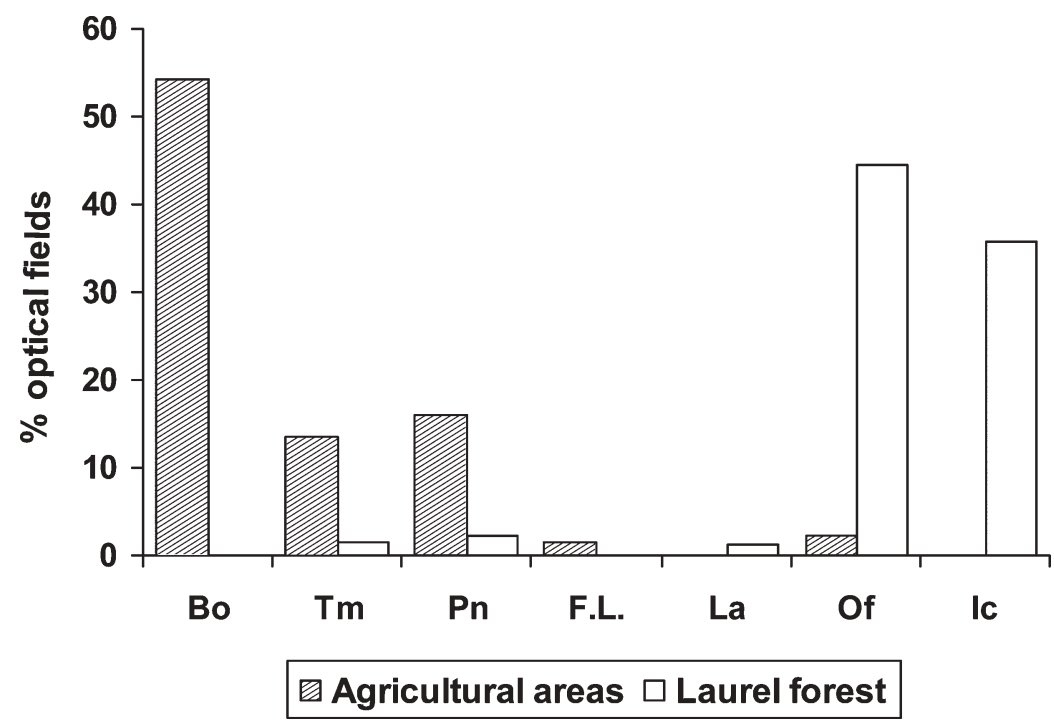

Figure 1. Principal species that appear in the droppings of Madeira Laurel Pigeon from two agricultural areas (Chão da Ribeira and Faial) and the laurel forest of Ribeira da Janela. All food items showed significant differences between the two habitats ( $G$ tests, P < o.001). Food items: Bo, Brassica cf. oleracea; Tm, Teline maderensis; Pn, Phyllis nobla; F.L., Family Lamiaceae; La, Laurus azorica; Of, Ocotea foetens; Ic, Ilex canariensis.

Teline maderensis and plants of the Lamiaceae family were frequently consumed in agricultural fields but scarcely in forest. However, fruits of Ocotea foetens and Ilex canariensis were preferred in the laurel forest, coinciding with the peak of fruit production for these plant species.

\section{Discussion}

The diet of Madeira Laurel Pigeon in the two agricultural study areas was dominated by the consumption of cabbage. Since this is the most common and widely cropped vegetable all over Madeira Island, such a level of consumption does not necessarily reflect strong selection or preference but likely an opportunistic diet. On the other hand it should be mentioned that many other common plants are not used, which could indicate some sort of selection. Pigeons used agricultural land in our study site in winter, coinciding with the sowing of young cabbage. Oliveira and Jones (2001) indicated that this pigeon uses agricultural fields between late February and July, with a peak of use towards the beginning of this period, which coincides with our findings.

Dietary composition suggests that despite the large movements carried out by the pigeons (Jones 1988, Oliveira et al. 2002), individuals that consume crops were relatively sedentary and some of them may actually specialize on agricultural crops, at least in winter. Despite the fact that we only studied two agricultural areas, Madeira Laurel Pigeon showed a tendency to specialize in sites far from forest areas, while this pattern changed to a broad food spectrum when the distance to laurel forest was shorter. 
Some authors have related the presence of pigeons in crops to a low availability of native food in forest (Bannerman and Bannerman 1965, Zino and Zino 1986). However, our findings suggest that this is not the case, because agricultural fields were used in winter when there is high fruit production (mainly Ocotea foetens and Ilex canariensis) in the laurel forest (Oliveira et al. 2002). Fruits were also the major component (85\%) in the pigeons' diet in the Ribeira da Janela laurel forest during the period when crops were being attacked. Some individuals may therefore have used crops during winter as an important complementary resource and not because of the scarcity of fruits in the laurel forest.

Although cabbage is considered to have poor nutritional value, causing weight loss in individual Woodpigeons (Murton et al. 1966), it seems that it is a popular food choice for at least some Madeira Laurel Pigeons. One possible explanation is that some birds may prefer feeding on very predictable and visible food sources rather than moving in search of less predictable ripe fruits. Other factors may be related to the local population density of the pigeons and the requirements for specific nutrients.

The damage caused by Madeira Laurel Pigeon on agricultural fields, and particularly to cabbages, has provoked the illegal killing of pigeons (Oliveira and Heredia 1996). In an attempt to resolve this problem, sound-scarers and exclusion nets have been employed successfully to keep birds away and protect crops. However, it is difficult to divert people from their traditional practices and persuade them to use these methods (Oliveira and Jones 2001).

The general unpopularity of Madeira Laurel Pigeon and illegal poisoning and shooting constitute the main threat to the species and further studies of the patterns of use of agricultural land are needed. It is also important to obtain more information on the physiological needs of Madeira Laurel Pigeon and the proportion of the population that use crops throughout the year.

\section{Acknowledgements}

We are very grateful to Pedro Oromí, Luisa Fernandes and Dília Menezes for providing logistic support. Seb Buckton, Frank Zino and Martin Jones revised the manuscript, providing us with interesting comments and suggestions. This paper was partially financed by the Serviço do Parque Natural da Madeira (E.C. Life project) and by a grant from the Universidad de La Laguna awarded to M.N.

\section{References}

Bannerman, D. A. and Bannerman, W. M. (1965) Birds of the Atlantic islands, vol. 2: A history of the birds of Madeira, the Desertas and the Porto Santo Islands. Edinburgh: Oliver and Boyd.

Costa Neves, H., Valente, A. V., Favila, B., Silva, I., Marques, J. C., Gouveia, N., Silva, P. and Oliveira, P. (1996) Laurissilva da Madeira. Caracterização quantitativa e qualitativa. Funchal: Secretaria Regional de Agricultura, Florestas e Pescas. Parque Natural da Madeira.

Herrera, C. M. (1998) Long-term dynamics of Mediterranean frugivorous birds and fleshy fruits: a 12-year study. Ecol. Monogr. 68: 511-538. 
Inglis, I. R., Isaacson, A. J., Thearle, R. J. P. and Westwood, N. J. (1990) The effects of changing agricultural practice upon Woodpigeon Columba palumbus numbers. Ibis 132: $262-272$.

Jiménez, R., Hódar, J. A. and Camacho, I. (1994) Diet of the woodpigeon (Columba palumbus) in the south of Spain during late summer. Folia Zool. 43: 163-170.

Jones, M. (1988) A survey of the distribution, density and habitat preferences of the Long-toed Pigeon Columba trocaz in Madeira. ICBP Study Rep. 32: 1-69.

Jordano, P. and Herrera, C. M. (1981) The frugivorous diet of Blackcap populations Sylvia atricapilla wintering in southern Spain. Ibis 123: 502-507.

Kenward, R. E. and Sibly, R. M. (1977) A woodpigeon (Columba palumbus) feeding preference explained by a digestive bottle-neck. J. Appl. Ecol. 14: 815-826.

Krebs, C. J. (1989) Ecological methodology. New York: Harper Collins.

Marrero, P. and Martín, C. (2000) Spring food preferences of rabbits (Oryctolagus cuniculus L., 1758) on the islet of Alegranza. Z. Saugetierkd. 65: 246-250.

Martín, A., Hernández, M. A., Lorenzo, J. A., Nogales, M. and González, C. (2000) Las palomas endémicas de Canarias. Santa Cruz de Tenerife: Consejería de Política Territorial y Medio Ambiente del Gobierno de Canarias, SEO/BirdLife.

Martínez, T. (1988) Utilisation de l'analyse micrographique des féces pour l'étude alimentaire du bouquetin de la Sierra Nevada (Espagne). Mammalia 52: 465-473.

Mohammad, A. G., Pieper, R. D., Wallace, J. D., Holechek, J. L. and Murray, L. W. (1995) Comparison of fecal analysis and rumen evacuation techniques for sampling diet botanical composition of grazing cattle. J. Range Manage. 48: 202-205.

Murton, R. K. and Jones, B. E. (1973) The ecology and economics of damage to Brassicae by wood-pigeons Columba palumbus. Ann. Appl. Biol. 75: 107-122.

Murton, R. K., Isaacson, A. J. and Westwood, N. J. (1966) The relationships between woodpigeons and their clover food supply and the mechanism of population control. J. Appl. Ecol. 3: 55-96.

Neff, J. A. (1947) Habits, food, and economic status of the Band-tailed Pigeon. Washington, D.C.: USDI Fish and Wildlife Service (North American Fauna 58).

Oliveira, P. and Heredia, B. (1996) Action plan for the Madeira Laurel Pigeon, Columba trocaz. Pp. 303-309 in B. Heredia, L. Rose and M. Painter, eds. Globally threatened birds in Europe. Action plans. Strasbourg, France: Council of Europe Publishing.

Oliveira, P. and Jones, M. (1995) Population numbers, habitat preferences and the impact of the Long-toed Pigeon, Columba trocaz, on agriculture. Bol. Mus. Mun. Funchal 4: $531-542$.

Oliveira, P. and Jones, M. (2001) Columba trocaz Madeira Laurel Pigeon. BWP Update 3: 111-117.

Oliveira, P., Rosa, A., Quintal, C., Menezes, D., Sousa, F., Fagundes, I., Sousa, L. and Pestana, N. (2001) Population trends between 1995 and 2000 and conservation status of the Madeira Laurel Pigeon, Columba trocaz. Proceedings book of the first symposium of island ecosystems: a conservation and molecular approach. Madeira.

Oliveira, P., Marrero, P. and Nogales, M. (2002) Diet of the endemic Madeira Laurel Pigeon and fruit resource availability: a study using microhistological analyses. Condor 104: 811-822.

Rumble, M. A. and Anderson, S. H. (1996) Feeding ecology of Merriam's Turkeys (Meleagris gallopavo merriami) in the Black Hills, South Dakota. Am. Midl. Nat. 136: 157-171.

Sherlock, M. G. and Fairley, J. S. (1993) Seasonal changes in the diet of Red Deer Cervus elaphus in the Connemara National Park. Biology and Environment. Proc. R. Irish Acad. 93: 85-90.

SPSS (1999) SPSS for Windows, release 10.o. Chicago: SPSS, Inc.

Zino, F. and Zino, P. A. (1986) An account of the habitat, feeding habits, density, breeding and need of protection of the Long-toed Pigeon, Columba trocaz. Bocagiana 88: 1-16. 
PATRICIA MARRERO and MANUEL NOGALES*

Island Ecology and Evolution Research Group, IPNA-CSIC, 38206, La Laguna, Tenerife, Canary Islands, Spain

\section{PAULO OLIVEIRA}

Serviço do Parque Natural da Madeira, Quinta Bom Sucesso, Caminho do Meio, 9050 Funchal, Madeira, Portugal

*Corresponding author. e-mail: mnogales@ipna.csic.es

Received 30 June 2003; revision accepted 10 March 2004 